\title{
THE IMPLEMENTATION OF SMALL GROUP TO IMPROVE STUDENTS' \\ ENGLISH SPEAKING (A CLASSROOM ACTION RESEARCH IN THE SIXTH GRADE STUDENTS OF ISLAMIC ELEMENTARY SCHOOL MIFTAHUL MUBTADIIEN ISLAMIYAH BANYAKAN KEDIRI IN THE
}

ACADEMIC YEAR 2013/2014

\author{
Pamadya Vitasmoro
}

\begin{abstract}
Speaking is one of the English skills which are taught at school. It means that English can be taught at Elementary school based on the needs of the school. In Elementary school, teacher teaches four language skills such as: listening, speaking, reading and writing to make students to be competence in English by mastering those four skills.

The students of Islamic Elementary School Miftahul Mubtadiien Islamiyah Banyakan faced some problems of speaking, such as they are afraid of making mistakes, they are shy of speak with other students, and they are low in speaking ability.

This study applied Classroom Action Research. The objectives of this study is to describe how small group can improve students' English speaking of the sixth grade students of Islamic Elementary School Miftahul Mubtadiien Islamiyah Banyakan, Kediri. In the sixth grade in which researcher found problem in the class and try to find the solution. The students of sixth grade students of Islamic Elementary School Miftahul Mubtadiin Islamiyah Banyakan Kediri. There are 28 students totally. There are divided into male and female. 12 students are male and 16 students are female. This was conducted in two cycles: the first cycle consists of three meetings and so was the second cycle.

The result of the research shows that (1) small group could improve students' speaking ability in term of raising students' achievement in the case of (a) fluency, (b) accuracy (pronunciation and Intonation) (2) small group can improve class situation, in term of (a) students' interaction when having and responding teacher's questions, (b) being active in small group activities, $(c)$ being more attentive to the speaking class, $(d)$ and the absence of students who were late and went out during speaking class, and (e) the unobservable dominancy of the teacher.
\end{abstract}

Keyword: Speaking, small group 


\section{Introduction}

Language is important for human being since language can be used to express his/her feeling to another people. Language is also used to communicate among people to get information, so language is media for delevering meaning and message. Good communication skills can help you to avoid conflict and solve problems. One of the international language is English.

Learning English is necessary now days. It is caused that English is an international language. That is why, English is taught from Elementary students until University students in Indonesia. It aims to make Indonesian people do not left behind with globalization era. In learning English, there are four skills which are important to be learnt, they are listening, speaking, reading, and writing. All those skills are supported by some components such as vocabulary, grammar, pronunciation, etc. Teaching English is necessary to start at Elementary school, it is first stage for children to learn something in order to develop their knowledge and in this period children are still easy to imitate something. Teaching English is a process of facilitating learning to the students, so they can receive and absorb the material as well as possible. According to Finachiaro in Nurhajati ( 1998: 15) "Young children are more plastic in their ability to learn new sound and that excelent opportunity is being lost when the young learners are not started on a language”. It means that young children are easier in learning and imitating a language 
because their speech organ is still developing.

Based on the statement above teaching English is very important to be introduced at Elementary school as a local subject, that statement is supported by Kasbolah in Nurhajati ( 1998: 2): "The legal basis of the teaching of English program in Elementary school is actually based on the Degree of stated that Education and Culture No. 487 / U / 1992. It was stated that extra lesson could be added as a local content when it was necessary".

In line with statement, Muslich in Nurhajati ( 1998: 2-3) adds, "Futhermore, based on the 1994 Curriculum English may be taugh in Elementary schools in certains areas starting from grade 4". It means that English can be taught at Elementary school based on the needs of the school. In Elementary school, teacher teaches four language skills such as: listening, speaking, reading and writing to make students to be competence in English by mastering those four skils. But in fact, the Elementary school student's skills are not balanced. Teacher teaches more in reading and writing than listening and speaking. It is suporrted by Admin ( 2008: 1), “...yet many English teachers still spend the majority of class time on reading and writing prectice almost ignoring speaking and listening skills". Many students consider that speaking is one of difficult subjects for them. Speaking has become the problems among students. These conditions were identified as the students are afraid of making mistake, shy of speak with other students, 
nervous, and doubt to speak. There were some causes of the mentioned problem above. The first cause was from the students. It was identified that the students have low of practicing. Then, students limit of vocabulary. Third, the students have lack of confidence to speak. Fourth, they find the difficulties in pronouncing English since they are not familiar with the English words. Fifth, the students is interferencing of the first language. Sixth, they are not be able to express their idea. From the teacher's point of view, the teaching learning process showed that it was monotonous. Teacher less monitored the students' activity. The technique which was applied during teaching learning process made the students in such boring situation. Based on the result of the preliminary research that the researcher did on October, 2013 showed that only 7 of 28 students who reached Kriteria Ketuntasan Minimal (KKM). The KKM in Islamic School Miftahul Mubtadiien Islamiyah Banyakan is 75 . The average score got by the students in preliminary test was 61.43

English teacher plays very important role in the success of teaching and learning activity. They must have a good method to make teaching learning process in speaking skill more enjoyable and meaningful. The teachers must be able to make the students participate in speaking actively. The English teacher should use appropriate approach, design, and procedures. By good method, it can help the students to be interested in learning speaking. This way can make students enjoy and have fun, and if the 
students enjoy and fun automatically they will be more confidence, students are not shy to speak and brave to speak since they do practicing speaking with their friends. “

Small group is suitable to teach speaking to Elementary students because they will have motivation and confidence to practice speaking in the class. The students like doing activities with other students to make them feel enjoy, fun, and have motivation.

\section{Method of Research}

In this chapter, the writer explains some sub chapters which relate to the title. Those sub chapters are young learners, speaking, teaching speaking, assessing and evaluating speaking, small group, small group in the classroom activities, and review of relevant research.

\subsection{Young Learners}

Scott and Ytreberg in Nurhajati (1998: 17) states that young learners mean chilldren from the first year of formal schooling (six to seven years old) to eleven or twelve years of age. The writer agree with that opinion since the term young learners are more focused on the children who sit in the elementary school as like indonesian schooling system. The first year of formal schooling in Indonesian, means that children start to learn in elementary school. They are six to seven years old. The year of elementary school are very important in their development which influence the way they learn English as they have unique characteristic.

Ismuni (2009: 3) points out some characteristics of young learners as follows: 
(a) They are happy when they can play. It means that children prefer learning by doing than sitting on the chair, (b) They love to share their experiences, they love when people play attention to them and th 2 :. talking. It means that chidren like getting attention from others when they tell their experiences and they are able to to talk about what they are doing, (c) children frequently learn inderictly rather than directly. It means that children understand language from the situation, gesture, actions or facial expression, (e) young children are already very good at interpreting meaning without necessarily understanding the individual words. It means that children have ability to the meaning even they did not know the meaning of every single word. They can understand from gesture or facial expresstion, (f) children take great pleasure in creating fun in what they do. It means that their physical activity is more dominan. Children have capatity for finding and making fun, (g) young children already have great skill in using limited lamgguage creatively. It means that children can use langguage in different situation and condition.

\subsection{Definition of Speaking}

Speaking is integral part of the whole personality of a speaker that expresses his or her social status and educational background. Speaking is used to communicate ideas, feelings, attitudes, and information by humans. Through speech activities, human can express his thought orally. Chaney says that speaking is the process of building and sharing meaning through the use of verbal and non verbal 
symbols, in a variety context, (in Kayi, 2007: p.1). The relation words and meaning is function of the evalution of specific language, not a function of the physical properties of words themselves, (Kuczaj 1999: 138).

\subsection{The Indicators of Speaking Competence}

Brown (2004: 141-142) says that the one can be called have speaking competence if she/he has a competence of namely; (a) he/she is able to imitate a word or phrase or possibly a sentence ( Imitative ability), (b) he/she is able to produce short stretches of oral language designed to demonstrate competence in a narrow band of grammatical, phrasal, lexical, or phonological relationship such as prosodic elements-intonation, stress, rhythm, juncture (intensive ability), (c) he/she is able to respond a very short conversation, standard greeting and small talk, simple request and comment, and the like (Responsive ability), (d) he/she is able to take the two forms of either transactional language which have the purose of maintaining social relationship (interactive ability), (e) or last if he/she is able to develop (monologue) oral production including speeches, oral presentation, and story telling, during which opportunity for oral interaction from listener is either highly limited or ruled out together (extensive ability).

From the statements above, it can be concluded that one has a certain language speaking competence if he/she can produce oral langauge to participate in any kind of activity. $\mathrm{He} / \mathrm{she}$ is able to respond to others' speaking to maintain his/ her social relationship. Besides, his/her language 
is acceptable and comprehensible at the level of language accuracy.

\subsection{Teaching Speaking}

According to Brown (2000: 7),

“ Teaching is guiding and facilitating learning, enable the learners to learn, sitting the conditions for teaching". Jarolimek in Dewi (2008: 7) states that teaching, is one aspect of education, it is an interaction between teacher, a person who include intelligent behaving, and learners, a person who is acquiring in intelligent which is one sub category. From those definitions teaching is a kind of activity and interaction between teacher and students that discuss about a subject. There are some students involve in it. The students can be young or old, female or male, high, average or low ability. The subject can be easy or difficult. The teacher may be male or female, handsome or not. But in most situations, in the teaching there are teacher, students and a subject. The definition of teaching to facilitate learning implies that teaching is tranferring knowlege that is very valuable. If the teaching activities do not have result in learning means that there is no teaching since in learning is lacking of quality, so the teaching is unsuccessful.

English teacher must create ways to teach in teaching speaking, here are some ways of teaching speaking to develop to the learner's knowledge (Brown and Nation, 2009: 3) such as: (a) The teacher present some new vocabulary or grammatical features, gives the learners some practice and then uses a meaning focused activity to help the learners speak on a topic or take a part in an 
activity, (b) before the learners speak on a topic or take a part in an activity, the work in pairs to prepare, (c) They prepare at home, using dictionaries, reference text, reading sources, and so forth, (d) many speaking activities involve some kind of written or picture input in the form of a worksheet, (e) some speaking activities encourage learners to ask each other about the meaning of unfamiliar words or construction.

\subsection{Definition of Small Work}

According to Hornby (1995) small is not large in size. Group is a number of people or things gathered. And discussion is to talk or write about something. So, small group is a few people to talk about something together.
Then according

to (http:///www.geogle.com) all group discussion is arrangement of students into small groups to participate in a range of activities to develop thinking or to complete practical tasks.

Based on the definition above, it can be concluded that small group discussion is small number of students to participate in some activities to develop some topic.

The purposes of small group are: to encourage participation in a non threatening environment, to maximize success, to develop collegial practices, to arrive at shared understanding, and to allow for focused teaching.

In general, group work has had a lot of emphasis in language classroom and its activities are taken 
place in some ways of the second language instructions, especially in encouraging learners' face to face practice. However, group activities still have got many problems when some students control the group a lot and make others uncomfortable, so how to organize group work effectively is the big question for educators and language teachers, who consider group wok as one of the best ways to improve students' speaking skill.

However, in a small group or as part of a pair, there is a sense of security because they are working with their classmates to come up with an answer or accomplish a task. There is no pressure on one solitary student. As a group or pair they share the responsibility for the work. They are also allowed the freedom to come up with answers that reflect their own thinking. This promotes the idea that there is often no correct answer, every important concept some language learners have a hard time grasping.

\section{Results and Discussion}

This chapter describes the research method used in this research. It involves the research design, setting and subjects of the research, and research procedure.

\section{a. Research Design}

This research was categorized as collaborative classroom action research since the researcher and one of the English teachers worked together in conducting the research. This design was employed in an effort to solve the students' problem in speaking ability. One of the popular definitions about CAR is proposed by 
Kemmis, Stephen in Hopkins, Davids

(1993: 44). He states that:

Action research is a form of self-reflective enquiry undertaken by participants in social (including education) situations in order to improve he rationality and justice of (a) their own social or educational practices (b) their understanding of these practices, and (c) the situation in which the practices are carried out. It is most rationally empowering when undertaken by participants collaboratively though it is often undertaken by individuals, and sometimes in cooperation with outsiders.

In conducting this research, the researcher made collaboration with one of the English teacher of MI Tiron Banyakan. The students involved in this research were the sixth grade students of MI Miftahul Mubtadiien Banyakan. In this research, the researcher and his collaborator had different roles. The researcher 27 the teacher who taught speaking with proposed technique. Meanwhile the collaborator acted as the observer observing the process of teaching and learning activities. Before conducting the activities of the research, the researcher firstly socialized the technique which would be used in the research to her and his students.

This research applied Classroom Action Research model proposed Kemmis and Mc Taggart (2002). It covered planning, implementing, observing, and reflecting.

The next step was to make a plan. In the planning stage, lesson plan was arranged and instructional material was prepared. Then, in the implementation stage, all the activities set in the lesson plan were implemented. The observation stage was done during the implementation of the action. Finally, the reflection and analysis of action were done to 
identify all facts including the success and the failure in the implementation stage.

In collecting the data in this research, the researcher took three ways. Those were test, observation, and field note.

This research is an action research which is implementing small group to improve students' speaking ability. The result this research was satisfying in term of: (1) the improvement of students' speaking ability; (2) the improvement of teaching learning process.

As it has been explained in the previous that classroom action research was done due real condition found during the preliminary study. It was found out that the students' speaking ability in the researcher' school was very low. When they were asked to do the best about speaking ability score was 40- 70. Through discussion between the researcher and his collaborator, it was concluded that some possible the students faced some problems of speaking, such as they are afraid of making mistakes, they are shy of speak with other students, and they are low in speaking ability. Those problem are influenced by some causes, such as having low of practicing, limiting of vocabulary, having lack of confidence to speak and also interferencing of the first language.

To solve the problem above, the researcher used pair work technique to improve the students' speaking ability. This was conducted in two cycles: the first cycle consists of three meetings 
and so was the second cycle. The activity in first meeting was reviewing the previous material, previewing what is going to learn, identifying the purpose of the meeting and introducing the topic or material. The activity in second meeting was reviewing the new vocabulary used, dividing the students to work in pairs, asking the students to practice the dialogue in their seat with the students which has good pronunciation, brave to speak up with the students which has low pronunciation and shy to speak up, giving assistance to the students in pairs, and noticing students' achievement. The third meeting was asks the students to practice in front of the class with the students which has good pronunciation, brave to speak up with the students which has low pronunciation and shy to speak up. The students should practice the dialogue with new partner or different partner, motivate the students and gave feedback The last activity was closing. In the closing activity, the researcher closed the lesson.

To speak fluency and accuracy, the students need to activate the cognitive process. Based on the findings, it showed that the implementation of small group in speaking class can improve the students' ability in speaking. It can be seen from the students' speaking progress and score among preliminary research.

Many students consider that speaking is one of difficult subjects for them. These conditions were identified as the students are afraid of 
making mistake, shy of speak with other students, nervous, and doubt to speak.. Based on the some problem above, the researcher used small work to solve that problem. By good method, it can help the students to be interested in learning speaking. This way can make students enjoy and have fun, and if the students enjoy and fun automatically they will be more confidence, students are not shy to speak and brave to speak since they do practicing speaking with their friends.

Small work creates a more secure and positive classroom atmosphere. For most students, being called on by the teacher to answer a question in front of their pairs can be a frightening experience. By applying small group in learning speaking, it gives the students more speaking time and allow them to use agreater variety of English to express what they really want to communicate. This type of work usually motivates students because it is quite simply more fun to work and talk with your classmates than it is to do tasks individually. By making lessons and activities more fun wecan stimulate students not just to come to class but to also enthusiastically contribute to theirown learning. In line with statement before, one of the main motivation to encourage small group in the English classroom is to increase the opportunities learners to use English in the class.

This chapter covers two things: conclusion and suggestions derived from the research finding and the discussion in the previous chapter. First is the conclusion of the research's 
finding to improve the students' ability in speaking using small group. While the later are suggestions aimed at teaching speaking by using small group for further research.

\section{Conclusion}

Using small group as a new strategy for the students of fifth grade students of Islamic Elementary School Miftahul Mubtadiien Islamiyah Banyakan Kediri can be applied as a good and effective strategy in solving the students' problem which are lack practice, shy to speak up and low in speaking ability. This strategy can improve the students' speaking ability.

The classroom situation was active, enjoyable and comfortable since the researcher give picture about daily activity, introduce or reminding the vocabulary first in each meeting and change in their partner, which the students has good pronunciation, brave to speak up with the students which has low pronunciation and shy to speak up.

After modifying the strategy applied, the improvement reached the target in which 24 students succeed with the average score 79,28

\section{REFERENCES}

Brown, H. Dauglas. 2000. Principle of Language Learning and Teaching. San Fransisco, Longman.

Brown, H. Dauglas. 2001. Teaching by Principle: An Interactive Approach to Language Pedagogy. New York. Longman.

Brown Douglas H. Teaching by Principles. An Interactive Approach to Language Pedagogy. 1994. Prentice Hall Regents. New Jersey.

Brown, H. Dauglas.1994. Principle of Language Teaching and Learning. San Fransisco: Practice Hall Regents.

Brown, H. Douglas. 2003. Language Assesment. Pronciples and Classroom Practice. Longman.

Burns, Anne. 1999. Focus on Speaking. National Centre for English Language Teaching and Research 
(NCELTR). Macquarie University. Sydney

Nunan, David. 1991. Language teaching Methodology. Prentice Hall Broughton.1978.

Channey.Chomsky.1988. Finnochiaro and Brumfit.2001.

Hughes, Rebecca. 2002. Teaching and Researching Speaking. London: Pearson Education.

Haycraft, John. 1978. An Introduction to English Language Teaching. England Longman Group Ltd.

Hornby, A.S.1995. Oxford Advanced Learner's Dictionary of Current English. Fifth Edition. Great Britain .Oxford University Press.

Hughes Rebbeca. 2002. Teaching and Researching Speaking. Pearson Education. Great Britain.

Harmer, Jeremy. 1998. How to Teach English. An Introduction to the Practice of English Language Teaching. London: Longman. London Publisher.

Hymes. J. Mc Keachi Wilbert. 1994. Teaching Tips. Canada

M. Jacobs George. 1995. Learning Cooperative Learning via Cooperative Learning.SEAMEO Regional Language Center. Singapore.

Nunan, David. 1997. The Learner Centered. Curriculum A Study in Second Language Teaching. Cambridge: Cambridge University Press. 